(c) American Dairy Science Association, 2003.

\title{
Optimizing the Level of Wet Corn Gluten Feed in the Diet of Lactating Dairy Cows
}

\section{J. W. Schroeder}

Department of Animal and Range Sciences,

North Dakota State University, Fargo 58105-5053

\section{ABSTRACT}

Twenty-four multiparous Holstein cows averaging $566 \pm 43 \mathrm{~kg}$ of body weight and $83 \pm 49 \mathrm{~d}$ in lactation were assigned to treatments stratified by age, days in milk, and milk yield to evaluate the effects of feeding increasing levels of wet corn gluten feed (WCGF) on lactational performance and milk composition. Complete diets containing $0,15,30$, or $45 \%$ of the total ration dry matter (DM) as WCGF were formulated to be $17.2 \%$ crude protein and $1.72 \mathrm{Mcal}$ of $\mathrm{NE}_{\mathrm{L}}$ per kilogram of DM, and fed twice daily to individual cows in Calan gates for $15 \mathrm{wk}$. All diets had a positive metabolizable protein balance. WCGF did not alter DM intake, but feed intake variance tended to be more consistent among cows fed 15 and 30\% WCGF (DM basis). Weight gain was numerically greatest for those cows receiving 45\% WCGF. Efficiency of energy and protein utilization was not different among treatments. Milk components of fat, protein, and casein were not different among treatments. Milk urea nitrogen was greater for cows on WCGF. Serum urea nitrogen was greatest in cows fed diets containing 15 and 45\% WCGF. Serum insulin was lowest in the groups receiving 30 and $45 \%$ WCGF, but serum glucose and total protein were unaffected. The concentration of the ruminal volatile fatty acid, valerate, was greater in cows on the WCGF diet and highest in cows fed 30\% WCGF. Ruminal ammonia was greatest in cows receiving $30 \% \mathrm{WCGF}$. It was estimated that $18.6 \%$ of the dietary DM fed as WCGF as a replacement for both portions of the concentrate and the forage in similar diets would have maximized milk yield without negatively affecting milk composition or feed efficiency.

(Key words: wet corn gluten feed, ruminant, milk yield and composition, dairy cow)

Abbreviation key: $\mathbf{M P}=$ metabolizable protein, $\mathbf{M U N}$ $=$ milk urea nitrogen, $\mathbf{W C G F}=$ wet corn gluten feed .

Received January 8, 2002

Accepted April 4, 2002.

Corresponding author:J. W. Schroeder; e-mail: jschroed@ndsuext. nodak.edu.

\section{INTRODUCTION}

Wet corn gluten feed (WCGF) is a relatively highfiber, medium-energy, medium-CP byproduct of the corn wet milling industry. This milling of corn results in byproducts that are excellent feedstuffs for dairy cattle (corn gluten meal, corn gluten feed, corn steep liquor, and corn bran). After the initial wet milling process, the bran is typically mixed with the steep liquor (condensed via centrifugation) in a ratio of about two parts bran plus one part condensed liquor to yield WCGF. This product contains about 40 to $45 \% \mathrm{DM}$ and is often flash-dried to about $90 \% \mathrm{DM}$ for dry corn gluten feed. Although WCGF has a nutritional advantage over the dried form, handling limits its appeal to many producers due to its limited shelf life (Droppo et al., 1985; Schroeder et al., 1998), thus offering a cost benefit to producers near a wet milling plant. The energy value of WCGF is 92 to $95 \%$ of the energy value of whole shelled corn (Firkins et al., 1985). However, variation in nutrient content of WCGF must be recognized. In a Tennessee study (Bernard and McNeill, 1991), considerable variation from a sole supplier was noted, requiring users to monitor WCGF composition.

With greater availability of WCGF to the Northern Great Plains area, questions from regional dairy producers regarding utilization of this byproduct have increased. The objectives of this research were to evaluate the effects of increasing levels of WCGF, when used to replace a portion of forage and barley grain on lactation performance, milk composition, blood metabolites, and rumen fermentation of multiparous, lactating Holstein cows.

\section{MATERIALS AND METHODS}

\section{Experimental Design}

Twenty-four multiparous Holstein cows averaging $566 \pm 43 \mathrm{~kg}$ of BW and $83 \pm 49 \mathrm{DIM}$ were assigned to a completely randomized design for $15 \mathrm{wk}$ at the North Dakota State University Dairy Research Center. Cows were stratified across treatments by age, DIM, and milk yield. TMR containing $0,15,30$, or $45 \%$ of the total dietary DM as WCGF (estimated to contain 1.92 Mcal 
Table 1. Ingredients and chemical composition of experimental rations to provide increasing levels of wet corn gluten feed (WCGF) to multiparous lactating Holstein cows.

\begin{tabular}{|c|c|c|c|c|}
\hline \multirow[b]{2}{*}{ Item } & \multicolumn{4}{|c|}{ WCGF } \\
\hline & 0 & 15 & 30 & 45 \\
\hline \multicolumn{5}{|l|}{ Ingredients ${ }^{1}$} \\
\hline WCGF & 0.0 & 15.0 & 30.0 & 45.0 \\
\hline Corn silage & 28.3 & 25.0 & 21.9 & 18.7 \\
\hline Alfalfa haylage & 16.5 & 14.7 & 12.8 & 10.9 \\
\hline Sunflower seed & 8.4 & 6.4 & 4.4 & 2.3 \\
\hline Barley $^{2}$ & 15.5 & 12.6 & 9.8 & 6.9 \\
\hline Soybean meal ${ }^{2}$ & 15.7 & 12.0 & 8.1 & 4.4 \\
\hline Beet pulp, dried ${ }^{2}$ & 11.3 & 10.0 & 8.7 & 7.5 \\
\hline Dicalcium phosphate $^{2}$ & 1.2 & 0.9 & 0.6 & 0.2 \\
\hline Limestone $^{2}$ & 0.5 & 0.8 & 1.1 & 1.5 \\
\hline Micronutrients and additives $^{2}$ & 2.6 & 2.6 & 2.6 & 2.6 \\
\hline \multicolumn{5}{|l|}{ Chemical analysis } \\
\hline $\mathrm{DM}, \%$ & 58.7 & 56.4 & 53.2 & 51.6 \\
\hline $\mathrm{CP}$ & 16.7 & 18.1 & 18.1 & 18.7 \\
\hline Lipid & 3.4 & 3.6 & 3.4 & 3.6 \\
\hline $\mathrm{ADF}$ & 27.5 & 25.6 & 20.9 & 21.0 \\
\hline $\mathrm{NDF}$ & 45.2 & 44.6 & 42.8 & 42.2 \\
\hline Calcium & 1.03 & 0.93 & 1.15 & 1.04 \\
\hline Phosphorus & 0.53 & 0.66 & 0.70 & 0.77 \\
\hline Ash & 9.51 & 9.36 & 10.59 & 10.82 \\
\hline
\end{tabular}

${ }^{1}$ Forage-to-concentrate ratio $=40: 60$. Calculated $\mathrm{NE}_{\mathrm{L}}$ values were $1.64,1.59,1.59,1.57 \mathrm{Mcal} / \mathrm{Kg}$ for 0,15 , $30,45 \%$ DM WCGF diets, respectively.

${ }^{2}$ Barley, soybean meal, dried beet pulp, dicalcium phosphate, limestone, micronutrients, and additives were premixed and pelleted for each diet. Micronutrients and additives consisted of $1 \%$ trace mineralized salt, $1 \%$ sodium bicarbonate, $0.29 \%$ magnesium oxide, $0.02 \%$ zinc methionine (Zinpro Corp., Eden Prairie, $\mathrm{MN})$, and $0.29 \%$ vitamin $\mathrm{A}(8,818,400 \mathrm{IU} / \mathrm{kg}), \mathrm{D}(1,763,680 \mathrm{IU} / \mathrm{kg})$, and $\mathrm{E}(2205 \mathrm{IU} / \mathrm{kg})$ premix.

$\mathrm{NE}_{\mathrm{L}}$ per $\mathrm{kg}$ of $\left.\mathrm{DM}\right)$ were formulated to be isonitrogenous $(17.2 \% \mathrm{CP})$ and isocaloric (1.72 $\mathrm{Mcal} \mathrm{NE}_{\mathrm{L}}$ per $\mathrm{kg}$ of $\left.\mathrm{DM}\right)$, with $25 \% \mathrm{NDF}, 0.86 \% \mathrm{Ca}$, and $0.55 \% \mathrm{P}$. The TMR were fed twice daily in amounts to ensure a 5 to $10 \%$ weigh back, with intake recorded daily using an electronic feeding gate system (American Calan, Northwood, NH). Samples from each load of WCGF were analyzed for nutrient and DM content upon arrival and, when necessary, ration adjustments were made based on compositional changes. Individual feeds were sampled and analyzed before the experiment, and diets were formulated as listed in Table 1. Cows were housed and handled under conditions described in animal and use protocols approved by the Institutional Animal and Care and Use Committee.

\section{Feed Processing}

Barley, soybean meal, beet pulp, and premixed ingredients (vitamins and minerals) were incorporated into a $9.5-\mathrm{mm}$ pellet processed in a California Pellet Mill, Hy-Flow Model (Crawfordsville, IN). Meal was conditioned using low-pressure steam $(103 \mathrm{kPa})$ to achieve 68 to $71^{\circ} \mathrm{C}$ before pellet pressing. Retention time for meal conditioning was approximately 9 to $10 \mathrm{~s}$ at an estimated 16 to $17 \%$ moisture.

\section{Sample Collection and Analyses}

Milk, blood, and ruminal fluid samples were collected during a 2-wk initialization period before the onset of the experiment. Daily production measures were assessed by monitoring total dietary DMI and milk yield of each cow. Cows were weighed for 3 consecutive days, and the weights were averaged. A BCS (Wildman et al., 1982) was assigned at the beginning and at the end of the 15-wk experiment. The diets were sampled before the beginning of the feeding trial and every $5 \mathrm{wk}$. Individual feed refusals, weighing approximately $1 \mathrm{~kg} / \mathrm{d}$ per cow, were also sampled during a consecutive 3 -d period of wk 5. The 3-d composite was subsampled for each of the experimental units (cow) for analysis. Individual feed components, TMR, and feed refusals were analyzed for DM, CP, ether extract, ash, Ca, and $\mathrm{P}$ according AOAC (1990) procedures. The ADF and NDF were determined by methods of Van Soest et al. (1991).

Milk, blood, and ruminal fluid samples were collected on the same 5-wk schedule. Milk samples were taken from four consecutive milkings and composited; milk was analyzed for CP (Kjeldahl), CN, fat (Babcock), and TS using standard AOAC (1990) procedures. Milk urea nitrogen (MUN) was determined using procedures described by Roseler et al. (1993) and a commercial kit 
(procedure 535; Sigma, St. Louis, MO). Cows were milked twice daily, and milk weights were recorded daily. Blood samples were withdrawn via coccygeal vein $3 \mathrm{~h}$ postfeeding, centrifuged $(1500 \times g)$ at $4^{\circ} \mathrm{C}$ for 20 min, and serum was decanted and stored at $-20^{\circ} \mathrm{C}$ until subsequent analysis. Serum was analyzed for glucose (procedure 510; Sigma), insulin (CAC radioimmunoassay kit; Diagnostic Products Corporation, Los Angeles, CA), total protein (Biuret method [Oser, 1965]), and urea N (procedure 640; Sigma). Ruminal fluid was extracted $3 \mathrm{~h}$ postfeeding via stomach pump, and samples were transported to the laboratory on ice. After determining $\mathrm{pH}$, ruminal fluid was acidified using metaphosphoric acid (25\%, wt/vol) according to Erwin et al. (1961) and frozen until further analysis. Ammonia was determined by a colorimetric procedure (modified procedure 640; Sigma), and ruminal fluid was analyzed by GLC (Shimadzu Scientific Instruments, Columbia, MD) for VFA (Goetsch and Galyean, 1983) using 2-ethyl butyric acid as an internal standard. Analysis was performed on a $30 \mathrm{~m} \times 0.32 \mathrm{~mm} \times 0.3 \mathrm{Fm}$ Superox-FA column (Alltech Assoc., Deerfield, IL) and under the following conditions: injector temperature $=180^{\circ} \mathrm{C}$, oven temperature $=145^{\circ} \mathrm{C}$, and carrier gas $=\mathrm{N}$ at $103 \mathrm{kPa}$.

\section{Statistical Methods}

ANOVA was conducted using SAS (1991) as a completely randomized design (Damon and Harvey, 1987). The MIXED procedure (Littell et al., 1996) was used for analysis of data. Means were separated when the $F$-test indicated significant treatment effects $(P<0.05)$. To compensate for unequal subclass numbers, least squares means and associated standard errors of the means were conducted using least significant difference (SAS, 1991). Pretrial data for each measure was initially used as a covariant, but not warranted $(P>0.30)$, and therefore was removed from the model. Cow was the experimental unit which was tested using the fixed effect terms of treatment, period, and treatment by period, where $\mathrm{n}=5$ for treatment 0 and $\mathrm{n}=6$ for treatments 15, 30, and 45. The random effects error term of cow (treatment) was used for all data except feed intake variance. This variable was computed for individual cows across days (Bauer et al., 1995) using treatment as the error term for the model. Orthogonal polynomials were used to test linear and quadratic responses for increasing levels of WCGF. Regression procedure of SAS (1991) was used to predict milk yield based on level of WCGF. Energetic efficiency (NRC, 2001) is expressed as Mcal $/ 100$ Mcal: energy $=((0.0929 \times \%$ milk fat $)+(0.0563 \times \%$ milk protein $)+0.192$ (constant for lactose $)) \times$ milk yield $(\mathrm{kg} / \mathrm{d})) \mathrm{DMI}(\mathrm{kg} / \mathrm{d}) \times$ dietary $\mathrm{NE}_{\mathrm{L}}$
Table 2. Chemical composition of wet corn gluten feed used in experimental rations for multiparous lactating Holstein cows.

\begin{tabular}{ll}
\hline Composition & \% of $\mathrm{DM}^{1}$ \\
\hline DM & $48.4 \pm 3.2$ \\
CP & $21.9 \pm 1.3$ \\
Lipid & $3.1 \pm 0.1$ \\
ADF & $9.8 \pm 0.3$ \\
NDF & $27.7 \pm 1.9$ \\
Calcium & $0.04 \pm 0.002$ \\
Phosphorus & $1.16 \pm 0.10$ \\
Potassium & $1.83 \pm 0.11$ \\
Ash & $8.12 \pm 0.16$ \\
\hline
\end{tabular}

${ }^{1}$ Average $\pm \mathrm{SD}, \mathrm{n}=4$, where samples were from separate loads delivered at 4 -wk intervals.

$(\mathrm{Mcal} / \mathrm{kg})$, and efficiency of protein utilization $=$ milk protein $(\mathrm{kg}) \times 100 /$ feed $\mathrm{CP}(\mathrm{kg})$.

\section{RESULTS AND DISCUSSION}

\section{Ration Composition}

The nutrient composition of WCGF may vary greatly among batches, $23.8 \pm 5.7 \% \mathrm{CP}$ and $35.5 \pm 6.8 \% \mathrm{NDF}$ (NRC, 2001). These variations in nutrient composition, especially $\mathrm{CP}$ and fiber, must be considered in diet formulation. Chemical analysis of each load of WCGF or purchasing WCGF with a guaranteed analysis may be required, and despite a guaranteed composition, further analysis is often warranted to accurately determine its contribution to the diets of high-producing dairy cows. Dietary formulation and nutrient analysis are shown in Table 1. All WCGF used in this experiment was received from the same source and found to have consistent composition (Table 2), even though each load was received at 4 -wk intervals. Although similar among treatments, diets did have a higher-than-expected NDF due to the high NDF content of corn silage (55\% NDF; Table 1). Both $\mathrm{Ca}$ and $\mathrm{P}$ were adjusted for each diet.

\section{Feed Intake and Efficiency}

Table 3 shows DMI, feed intake variance, BCS, BW gain, and efficiency of cows fed increasing levels of WCGF. Increasing the level of WCGF up to $45 \%$ (DM basis) did not change DMI or intake as a percentage of BW; however, feed intake variance $\left(\mathrm{kg}^{2} / \mathrm{d}\right)$ among cows within treatment resulted in a quadratic response $(P<$ 0.07 ), where 0 and $45 \%$ WCGF-fed cows tended to have more variable daily feed intakes. Since erratic consumption at higher levels of WCGF inclusion is common, it remains important for managers to closely examine diet composition, especially for the fiber source and its particle size (Allen and Grant, 2000). Even with the tendency for increased daily variation, average daily DMI was not different among treatments. 
Table 3. Least squares means for feed intake, feed efficiency, BW, and condition of multiparous lactating Holstein cows fed increasing levels of wet corn gluten feed (WCGF).

\begin{tabular}{|c|c|c|c|c|c|c|c|c|}
\hline \multirow[b]{2}{*}{ Item } & \multicolumn{4}{|c|}{ WCGF, \% DM } & \multirow[b]{2}{*}{$\mathrm{SEM}^{1}$} & \multirow[b]{2}{*}{$P$} & \multicolumn{2}{|c|}{ Contrast } \\
\hline & 0 & 15 & 30 & 45 & & & Linear & Quadratic \\
\hline \multicolumn{9}{|l|}{ DMI } \\
\hline $\mathrm{kg} / \mathrm{d}$ & 21.9 & 24.4 & 22.4 & 21.9 & 1.3 & 0.40 & 0.71 & 0.22 \\
\hline$\%$ of $\mathrm{BW}$ & 3.65 & 3.97 & 3.77 & 3.51 & 0.26 & 0.57 & 0.59 & 0.24 \\
\hline Intake variance, $\mathrm{kg}^{2} / \mathrm{d}$ & 14.7 & 6.1 & 8.8 & 12.4 & 3.3 & 0.27 & 0.76 & 0.07 \\
\hline Energy, Mcal/100 Mcal & 50.9 & 52.9 & 49.7 & 47.4 & 3.5 & 0.68 & 0.38 & 0.52 \\
\hline Protein, kg/100 kg & 23.2 & 22.4 & 22.0 & 20.6 & 1.4 & 0.57 & 0.18 & 0.82 \\
\hline BCS, $(1 \text { to } 5)^{3}$ & 2.7 & 2.5 & 2.7 & 2.9 & 0.19 & 0.58 & 0.30 & 0.44 \\
\hline $\mathrm{BW}$ gain, $\mathrm{kg}^{4}$ & 29.6 & 46.2 & 45.5 & 62.6 & 10.16 & 0.16 & 0.04 & 0.98 \\
\hline
\end{tabular}

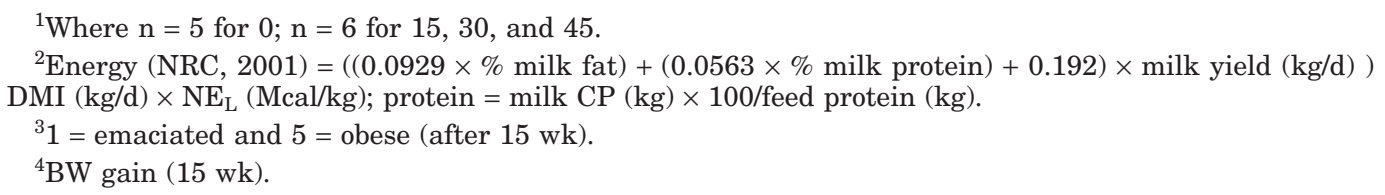

Cows receiving the highest level of WCGF (45\% DM basis) appeared to be gaining more BW (Table 3) as evidenced by a positive linear $(P<0.04)$ relationship, but differences were not significant. BCS was also similar among treatments over the 15 -wk feeding period. While cows fed $45 \%$ WCGF had acceptable BCS, the added BW during late lactation could be a concern for cows with a tendency for excess fat deposition, predisposing high-producing dairy cows to related metabolic disorders. Conversely, the use of WCGF could improve the BCS of thin cows.

Measures used to calculate energy and protein utilization were not different among treatments. In contrast, Staples et al. (1984) and Droppo et al. (1985) noted that greater levels of WCGF reduced energetic efficiency. They attributed the reduction to depressed $\mathrm{NE}_{\mathrm{L}}$ in combination with increased DMI. Efficiency of feed utilization appeared to be at the expense of BW gains when dried corn gluten feed was used to replace barley as the nonfiber carbohydrate source (Schroeder and Park, 1995). Our earlier work suggested that corn gluten feed in the dried form may be limited to approximately $30 \%$ of the total DMI for high-producing cows. In the present experiment, dietary $\mathrm{NE}_{\mathrm{L}}$ calculations (NRC, 2001) of $1.64,1.59 .1 .59$, and $1.57 \mathrm{Mcal} / \mathrm{kg} \mathrm{DM}$ for treatments $0,15,30$, and $45 \%$, respectively, do not reflect an energetic deficiency, given the similarity of energy supplied in these diets. Energy efficiency, a function of both DMI (Table 3) and milk yield (Table 4) and as described in NRC (2001) was not different among treatments. Efficiency of protein utilization also was not altered by treatment.

\section{Milk Yield and Composition}

Even though intake variation was less among cows fed 15 and 30\% WCGF, the actual milk yield, 3.5\%
FCM, and SCM (Table 4) were not different for cows fed increasing levels of WCGF. However, a quadratic response for actual, 3.5\% FCM, and SCM yield was seen $(P<0.15, P<0.10$, and $P<0.10$, respectively) with increasing levels of WCGF. Using REG procedures of SAS (1991), the optimum level of WCGF inclusion for maximum milk yield from these diets was estimated (Figure 1). The curvilinear determination predicts that under these conditions, $18.6 \%$ of this diet as WCGF would result in maximum milk yield (actual) of 32.4 $\mathrm{kg} / \mathrm{cow}$ per day for cows of similar DIM. This agrees with Staples et al. (1984), who fed diets containing 0, 20,30 , and $40 \%$ of DM as WCGF. They reported a decrease in DMI and milk yield when greater than $20 \%$ WCGF replaced portions of the corn grain and soybean meal in diets that contained 50\% corn silage. Droppo et al. (1985) also replaced a portion of the grain and soybean meal with WCGF and reported decreases in DMI and milk yield when WCGF is increased from 18.6 to $37.1 \%$ of the diet DM. However, VanBaale et al. (2001) concluded that when WCGF is substituted for both a portion of the forage and grain (corn) in the diet, primiparous and multiparous cows will have increased yield of FCM and increased DMI. Although not significant, the present study suggests a similar pattern of intake and milk yield when adding 15 to $30 \%$ WCGF (DM basis) to the diet.

Milk fat and TS increased linearly $(P<0.05$ and $P<$ 0.03 , respectively) with increasing levels of WCGF but were not different among treatments (Table 4). Total milk protein and $\mathrm{CN}$ were not altered. Staples et al. (1984) found that cows fed 20\% WCGF yield more milk, with a higher fat content than that of cows fed a $0 \%$ WCGF diet. Macleod et al. (1985) found that milk fat increased only during late lactation, while milk protein decreased when cows are fed high levels of WCGF 
Table 4. Least squares means for milk yield and composition of multiparous lactating Holstein cows fed increasing levels of wet corn gluten feed (WCGF).

\begin{tabular}{|c|c|c|c|c|c|c|c|c|}
\hline \multirow[b]{2}{*}{ Item } & \multicolumn{4}{|c|}{ WCGF, \% DM } & \multirow[b]{2}{*}{$\mathrm{SEM}^{1}$} & \multirow[b]{2}{*}{$P$} & \multicolumn{2}{|c|}{ Contrast } \\
\hline & 0 & 15 & 30 & 45 & & & Linear & Quadratic \\
\hline Actual milk, $\mathrm{kg} / \mathrm{d}$ & 28.8 & 33.7 & 29.7 & 26.7 & 2.79 & 0.31 & 0.41 & 0.15 \\
\hline $3.5 \% \mathrm{FCM}, \mathrm{kg} / \mathrm{d}$ & 26.1 & 31.6 & 29.5 & 26.9 & 2.64 & 0.39 & 0.97 & 0.10 \\
\hline $\mathrm{SCM}, \mathrm{kg} / \mathrm{d}$ & 28.8 & 35.3 & 32.6 & 30.3 & 2.81 & 0.36 & 0.88 & 0.10 \\
\hline Milk fat, \% & 2.93 & 3.12 & 3.44 & 3.48 & 0.20 & 0.16 & 0.03 & 0.67 \\
\hline $\mathrm{CP}, \%$ & 2.93 & 2.99 & 3.00 & 3.13 & 0.10 & 0.53 & 0.19 & 0.68 \\
\hline $\mathrm{CN}, \%$ & 1.89 & 2.02 & 1.86 & 2.04 & 0.10 & 0.40 & 0.47 & 0.80 \\
\hline $\mathrm{TS}, \%$ & 11.34 & 11.64 & 11.80 & 12.12 & 0.29 & 0.27 & 0.05 & 0.97 \\
\hline Milk urea N (mg/dl) & $15.37^{\mathrm{b}}$ & $16.25^{\mathrm{ab}}$ & $16.83^{\mathrm{a}}$ & $17.34^{\mathrm{a}}$ & 0.44 & 0.02 & 0.01 & 0.66 \\
\hline
\end{tabular}

${ }^{1}$ Where $\mathrm{n}=5$ for $0 ; \mathrm{n}=6$ for 15,30 , and 45 .

a,b,c Means within a row without common superscripts differ $(P<0.05)$.

(37.1\%, DM basis). Boddugari et al. (1999) observed reductions in DMI and milk protein percentage, but not differences in milk yield and efficiency of FCM production when WCGF replaced 50,75 , or $100 \%$ of the grain mix in diets containing $54.3 \%$ forage. Gunderson et al. (1988) fed 0, 10, 20, and 30\% WCGF (DM basis) and found no difference in milk yield or milk composition. Similarly, Armentano and Dentine (1988) substituted $2.6,5.3$, or $7.9 \mathrm{~kg}$ of WCGF (DM basis) for 2.4, 4.7, and $7.2 \mathrm{~kg}$ of concentrate DM, respectively, in diets for lactating cows and reported no differences in milk yield or composition among these diets. According to Allen and Grant (2000) fiber digestion is sustained when sufficient amounts of WCGF are fed, explaining why milk

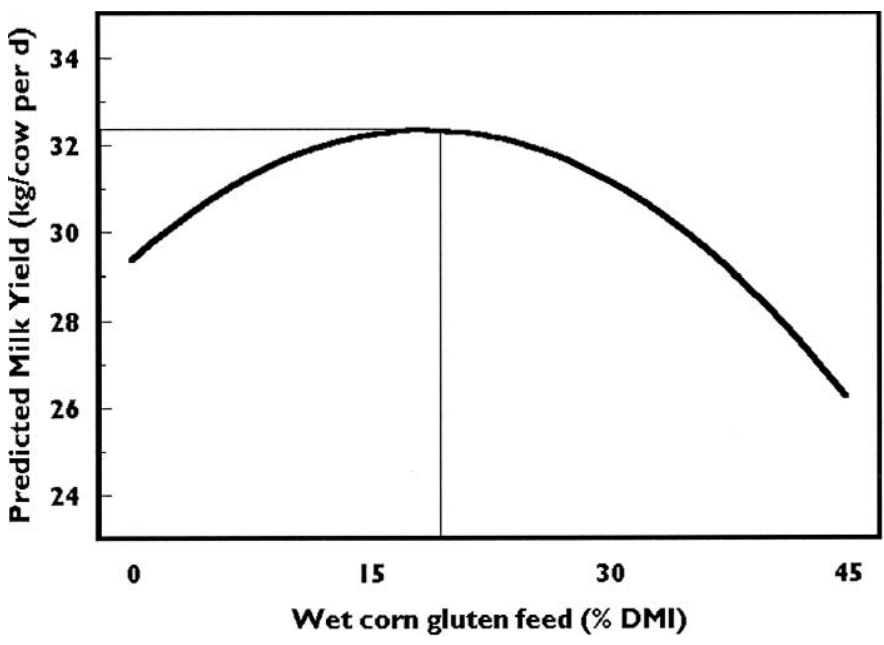

Figure 1. Predicted milk yield of multiparous lactating Holstein cows fed increasing levels of wet corn gluten feed (WCGF). Values are expressed as kilograms of actual milk yield least squares means for a quadratic response, where $\mathrm{n}=5$ for 0 and $\mathrm{n}=6$ for 15,30 , and 45. Treatment $\mathrm{r}^{2}=0.15 ; \hat{\mathrm{Y}}=29.35 \pm 1.352+0.32 \pm 0.139 \mathrm{x}+(-0.009$ $\pm 0.003) x^{2}$. The optimum level of dietary WCGF was calculated to be $18.6 \%$ of the DMI for a maximum milk yield of $32.3 \mathrm{~kg} / \mathrm{cow}$ per $\mathrm{d}$, where $\mathrm{x}=$ level of WCGF (DM basis). fat improves. Diets formulated to complement the characteristics in WCGF, rather than a single substitution for components of either forage or grain, will increase the likelihood of optimizing its use in a lactation regimen (VanBaale et al., 2001). VanBaale et al. (2001) concluded that milk protein, fat, and SNF percentage are unaffected by dietary level of WCGF in primiparous cows, but milk fat is depressed in multiparous cows, likely the result of dilution of milk fat by increased milk yield.

WCGF is relatively low in starch (18 to $22 \%$ of DM) and high in NDF ( $42 \%$ of $\mathrm{DM})$, with a $\mathrm{CP}$ fraction that is very degradable (65\%) in the rumen (Firkins et al., 1984). However, large proportions (40 to $60 \%$ of DM) of WCGF appear to limit intake of lactating cows (Fellner and Belyea, 1991). Yet, in corn silage-based diets, WCGF is equal to corn in supporting animal gains (Kampman and Loerch, 1989). In the present experiment, when substituting WCGF for portions of both grain (barley and soybean) and forages (alfalfa and corn silage), the differences in production responses were less apparent.

\section{Blood Parameters and Ruminal VFA}

Serum glucose and total protein were similar among treatments, but insulin was lower $(P<0.01)$ in cows fed diets containing WCGF (Table 5). The lowest serum insulin levels were in the cows fed 15 and 30\% WCGF. These levels responded in a quadratic fashion, first decreasing and then increasing $(P<0.01)$.

Cows on diets containing WCGF had greater $(P<$ 0.02) concentrations of MUN (Table 4). Similarly, serum urea nitrogen (Table 5) was also higher in cows on diets containing WCGF, with the 30\%-WCGF group having the greatest $(P<0.02)$ levels. Both MUN and serum urea nitrogen levels of cows from the $15 \%$-WCGF treatment were not different from the $0 \%$-treatment, and both measures increased $(P<0.01)$ linearly in re- 
Table 5. Least squares means for serum metabolites and ruminal VFA percentages, $\mathrm{pH}$, and ammonia of multiparous lactating Holstein cows fed increasing levels of wet corn gluten feed (WCGF).

\begin{tabular}{|c|c|c|c|c|c|c|c|c|}
\hline Item & \multicolumn{4}{|c|}{ WCGF, \% DM } & $\mathrm{SEM}^{1}$ & $P$ & \multicolumn{2}{|c|}{ Contrast } \\
\hline \multicolumn{9}{|l|}{ Serum } \\
\hline Insulin $(\mu \mathrm{IU} / \mathrm{ml})$ & $19.60^{\mathrm{a}}$ & $12.05^{\mathrm{c}}$ & $15.37^{\mathrm{b}}$ & $18.04^{\mathrm{ab}}$ & 1.62 & 0.01 & 0.84 & 0.01 \\
\hline Glucose (mg/dl) & 66.68 & 65.17 & 62.91 & 65.93 & 2.09 & 0.57 & 0.62 & 0.26 \\
\hline Total protein $(\mathrm{g} / \mathrm{dl})$ & 7.72 & 7.60 & 7.33 & 7.33 & 0.21 & 0.43 & 0.13 & 0.77 \\
\hline Butyrate & 14.32 & 13.99 & 13.98 & 12.51 & 0.53 & 0.08 & 0.03 & 0.27 \\
\hline Isobutyrate & 1.35 & 1.43 & 1.50 & 1.64 & 0.11 & 0.27 & 0.06 & 0.77 \\
\hline Valerate & $2.79^{c}$ & $3.45^{\mathrm{ab}}$ & $4.09^{\mathrm{a}}$ & $3.38^{\mathrm{b}}$ & 0.25 & 0.01 & 0.03 & 0.01 \\
\hline Isovalerate & 2.29 & 2.58 & 2.43 & 2.57 & 0.27 & 0.85 & 0.57 & 0.77 \\
\hline Total VFA $(\mathrm{m} M)$ & $112.52^{\mathrm{ab}}$ & $113.18^{\mathrm{ab}}$ & $127.46^{\mathrm{a}}$ & $93.85^{\mathrm{b}}$ & 8.59 & 0.05 & 0.27 & 0.05 \\
\hline $\mathrm{A}: \mathrm{P}$ ratio & 2.92 & 2.76 & 2.75 & 2.98 & 0.17 & 0.66 & 0.81 & 0.24 \\
\hline $\mathrm{pH}$ & 6.51 & 6.56 & 6.38 & 6.86 & 0.14 & 0.09 & 0.17 & 0.12 \\
\hline
\end{tabular}

${ }^{1}$ Where $\mathrm{n}=5$ for $0 ; \mathrm{n}=6$ for 15,30 , and 45 .

${ }^{\mathrm{a}, \mathrm{b}, \mathrm{c}}$ Means within a row without common superscripts $\operatorname{differ}(P<0.05)$.

sponse to increasing levels (30 and 45\%) of WCGF. These results are similar to those of VanBaale et al. (2001), who found that plasma urea $\mathrm{N}$ was greater in cows fed WCGF, and the greatest $(P<0.01)$ MUN levels were in cows fed 27.5 and $35 \%$ WCGF.

Both MUN and blood urea $\mathrm{N}$ levels tend to vary greatly, and normal values are not well established. Although MUN target values have changed (September 1998) from 12 to $16 \mathrm{mg} / \mathrm{dl}$ to a range of 8 to $12 \mathrm{mg} /$ $\mathrm{dl}$, these data were collected before that adjustment of calibration standards for MUN analysis reported by the National Dairy Herd Improvement Association (Kohn et al., 2001) Using references current to data collection, cows with MUN levels less than 10 to $12 \mathrm{mg} / \mathrm{dl}$ or more than 16 to $18 \mathrm{mg} / \mathrm{dl}$ are reported to be losing nutrients, which results in higher feed costs, reduced health and reproductive performance, and lower milk production (Linn and Olson, 1995). Given the formerly accepted range for lactating cows, the MUN in this study increased as WCGF level increased, indicative of an excessive supply of RDP. Such results would support increasing microbial incorporation of RDP into microbial protein, or supplementing WCGF with RUP when it is limiting to balance protein needs. The balance for RDP, metabolizable protein (MP), and essential AA were calculated by using the NRC (2001) Computer Model Program for Predicting Nutrient Requirements. The estimates were determined using treatment averages for actual milk yield, milk fat, and milk protein along with the chemical analysis reported in Table 1 for each diet. All diets had a positive RDP balance (502, 585, 556, and $567 \mathrm{~g} / \mathrm{d}$ for $0,15,30$, and $45 \% \mathrm{WCGF}$, respectively). The MP balance was 246, 173, 159, and $181 \mathrm{~g} / \mathrm{d}$, for diets of $0,15,30$, and $45 \%$ WCGF, respectively, and the estimated duodenal supply of essential AA was 43.96, $43.32,43.25$, and $42.99 \%$ of MP for the respective diets.

Both serum urea nitrogen and MUN concentrations increased linearly $(P<0.01)$, while milk yield only tended to decrease with increasing levels of WCGF. It is possible that the reduction in actual milk yield, FCM, and SCM in cows fed 30 and $45 \%$ WCGF was the result of costs associated with metabolic energy being expended to convert and excrete urea. The scenario that much of the urea is derived from ruminal ammonia suggests that whole-body energetic costs are reflected in decreased adjusted milk yield (Huntington and Archibeque, 1999). However, the dietary sources of ammonia en route to the liver are many and varied (Reynolds, 1992; Meijer et al., 1999). The positive energy $\left(\mathrm{NE}_{\mathrm{L}}\right)$ balance of the experimental diets (NRC, 2001) suggests that it is unlikely that the energetically expensive urea cycle was responsible for the tendency towards decreasing milk yield in the diets containing the greatest levels of WCGF. Furthermore, the positive RDP balance of the treatment diets suggests that MP and essential AA were adequate. In another experiment, Schroeder and Park (1998) adjusted RUP and RDP of diets with 19\% WCGF (DM basis). They found that lowering CP degradability in the diet increases milk CN level, but milk yield was not affected.

The VFA data are presented in Table 5. Butyrate decreased linearly $(P<0.03)$ with increasing amounts of WCGF and was lowest in cows fed $45 \%$ WCGF. Valerate was lowest $(P<0.01)$ in the control group, followed by the 45\%-WCGF group, and exhibited both linear $(P<$ $0.03)$ and quadratic $(P<0.01)$ relationships to increas- 
ing amounts of WCGF. The levels of dietary WCGF did not affect the other ruminal VFA but did result in lower $(P<0.05)$ total VFA concentrations for cows fed $45 \%$ WCGF. The acetate-to-propionate ratio was not changed, but ruminal $\mathrm{pH}$ differences among WCGF levels were evident $(P<0.09)$. Ruminal ammonia concentrations responded quadratically $(P<0.01)$ to increasing levels of WCGF and were greatest $(P<0.01)$ for the $30 \%$-WCGF treatment. In general, the ruminal measurements were not markedly different, which agrees with the observation of Firkins et al. (1985). The differences in butyrate and valerate, along with the lower $(P$ $<0.05$ ) total ruminal VFA concentrations for cows fed $45 \%$ WCGF may suggest reduced fermentation or greater absorption.

\section{CONCLUSIONS}

When WCGF is substituted for both a portion of dietary concentrate and forage DM, apparent utilization of nutrients is similar. These results indicate that based on milk yield, simple substitution of WCGF can replace from 15 to $30 \%$ of dietary DM. Up to $45 \%$ WCGF (DM basis) appears acceptable when diets are adjusted for both fiber and energy. However, feeding up to $45 \%$ WCGF may not be advisable for producers, given established requirements for $\mathrm{P}$. The $\mathrm{P}$ concentration of the diets was increased further with added WCGF, an inherent challenge for nutritionists using this ingredient. Although this is not the focus of the research, the implications of feeding extremely high rates of WCGF on dietary $\mathrm{P}$ balance must be considered from a practical standpoint. The optimum level of WCGF inclusion for maximum milk yield in dairy cows fed these diets was $18.6 \%$ of the diet DM. Diet formulation should account for variations in $\mathrm{CP}, \mathrm{MP}$, and RDP when feeding WCGF and may explain some of the decline in feed efficiency reported in the literature. As greater levels of WCGF are included in the diet, variation of daily DMI may become a factor. In spite of its special considerations when transporting, handling, and storing, WCGF is an excellent byproduct feedstuff for dairy cattle when economics are favorable and limitations are taken into account.

\section{ACKNOWLEDGMENTS}

The author is especially grateful to C. S. Park for his expertise, and to the dependable support of the research farm technicians and herdsman at North Dakota State University. I further express my gratitude to M. L. Bauer for his editing comments and to D. V. Dhuyvetter for collaborative funding efforts. Lastly to W. L. Keller for her technical skills, coordinating all bench-top labo- ratory analysis, and further editing. This research was funded in part through collaboration with North Dakota Agricultural Products Utilization Commission and Midwest Agri-Commodities Company.

\section{REFERENCES}

Allen, D. M., and R. J. Grant. 2000. Interactions between forage and wet corn gluten feed as sources of fiber in diets for lactating dairy cows. J. Dairy Sci. 83:322-331.

Armentano, L. E., and M. R. Dentine. 1988. Wet corn gluten feed as a supplement for lactating dairy cattle and growing heifers. J. Dairy Sci. 71:990-995.

Association of Official Analytical Chemists. 1990. Official Methods of Analysis. Vol. I. 15th ed. AOAC, Arlington, VA.

Bauer, M. L., D. W. Herold, R. A. Britton, R. A. Stock, T. J. Klopfenstein, and D. A. Yates. 1995. Efficacy of laidlomycin propionate to reduce ruminal acidosis in cattle. J. Anim. Sci. 73:3445-3554.

Bernard, J. K., and W. W. McNeill. 1991. Effect of high fiber energy supplements on nutrient digestibility and milk production of lactating dairy cows. J. Dairy Sci. 74:991-995.

Boddugari, K., R. J. Grant, R. Stock, and M. Lewis. 1999. Maximal replacement of dietary concentrate and forage with a new wet corn milling feed product. Pages 11-14 in 1999-2000 Nebraska Dairy Report. Univ. of Nebraska Coop. Ext., Lincoln, NE.

Damon, R. P., and W. R. Harvey. 1987. Experimental Design, ANOVA, and Regression. Harper and Row, New York, NY.

Droppo, T. E., G. K. Macleod, and D. G. Grieve. 1985. Composition and storage characteristics of wet corn gluten feed. Can. J. Anim. Sci. 65:265-268.

Erwin, E. S., D. J. Marco, and E. M. Emery. 1961. Volatile fatty acid analysis of blood and rumen fluid by gas chromatography. J. Dairy Sci. 44:1768-1769.

Fellner, V., and R. L. Belyea. 1991. Maximizing gluten feed in corn silage diets for dairy cows. J. Dairy Sci. 74:996-1005.

Firkins, J. L., L. L. Berger, and G. C. Fahey, Jr. 1985. Evaluation of wet and dry distillers grains and wet and dry corn gluten feeds for ruminants. J. Anim. Sci. 60:847-860.

Firkins, J. L., L. L. Berger, G. C. Fahey, Jr., and N. R. Merchan. 1984. Ruminal nitrogen degradability and escape of wet and dry distillers grains and wet and dry corn gluten feeds. J. Dairy Sci. 67:1936-1944.

Goetsch, A. L., and M. L. Galyean. 1983. Influence of feeding frequency on passage of fluid and particulate markers in steers fed a concentrate diet. Can. J. Anim. 63:727-730.

Gunderson, S. L., A. A. Aguilar, D. E. Johnson, and J. D. Olson. 1988. Nutritional value of wet corn gluten feed for sheep and lactating dairy cows. J. Dairy Sci. 71:1204-1210.

Huntington, G. B., and S. L. Archibeque. 1999. Practical aspects of urea and ammonia metabolism in ruminant. Proc. Am. Soc. Anim. Sci. Online. Available at http://www.asas.org/jas/symposia/proceedings/0939.pdf.

Kampman, K. A., and S. C. Loerch. 1989. Effects of dry corn gluten feed on feedlot cattle performance and fiber digestibility. J. Anim. Sci. 67:501-512.

Kohn, R. A., K. F. Kalscheur, and E. Russek-Cohen. 2001. Evaluation of models to predict urinary excretion and milk urea nitrogen. J. Dairy Sci. 84(Suppl. 1):162 (Abstr.).

Linn, J. G., and J. D. Olson. 1995. Using milk urea nitrogen to evaluate diets and reproductive performance of dairy cattle. Pages 155-167 in 4-State Applied Nutr. and Management Conf., LaCrosse, WI, Univ. of Wisconsin, Madison, WI.

Littell, R. C., G. A. Milliken, S. W. Walter, and R. D. Wolfinger. 1996. SAS Systems for Mixed Models, SAS Inst., Inc., Cary, NC.

Macleod, G. K., T. E. Droppo, D. G. Grieve, D. J. Barney, and W. Rafalowski. 1985. Feeding value of wet corn gluten feed for lactating dairy cows. Can. J. Anim. Sci. 65:125-134.

Meijer, A. J., E. F. C. Blommaart, P. F. Dubbelhuis, and D. A. van Sluijters. 1999. Regulation of hepatic nitrogen metabolism. Pages 155-175 in Protein Metabolism and Nutrition. Proc. VIII Int. 
Symp. Protein Metabolism Nutr. EAAP Publication No. 96. G. E. Lobley, A. White, and J. C. MacRae, ed. Wageningen Pers, Aberdeen, United Kingdom.

National Research Council, 2001. Pages 281-314 in Nutrient Requirements of Dairy Cattle. 7th rev. ed. Natl. Acad. Sci., Washington, DC.

Oser, B. L., 1965. Hawk's Physiological Chemistry. 14th ed. McGrawHill, New York, NY

Reynolds, C. K. 1992. Metabolism of nitrogenous compounds by ruminant liver. J. Nutri. 122:850-854.

Roseler, D. K., J. D. Ferguson, C. J. Sniffen, and J. Herrema. 1993. Dietary protein degradability effects on plasma and milk urea nitrogen and milk nonprotein nitrogen in Holstein cows. J. Dairy Sci. 76:525-534.

SAS User's Guide: Statistics, Version 8.01 Edition. 1991. SAS Inst., Inc., Cary, NC.

Schroeder, J. W., and C. S. Park. 1998. Altering protein degradability and storage form of wet corn gluten feed in diets of lactating dairy cows. J. Dairy Sci. 81(Suppl. 1):338 (Abstr.)
Schroeder, J. W., and C. S. Park. 1995. The effect of dietary supplementation of dried corn gluten feed to diets of lactating dairy cows. J. Dairy Sci. 78(Suppl. 1):244 (Abstr.)

Staples, C. R., C. L. Davis, G. C. McCoy, and J. H. Clark. 1984. Feeding value of wet corn gluten feed for lactating dairy cows. J. Dairy Sci. 67:1214-1220.

VanBaale, M. J., J. E. Shirley, E. C. Titgemeyer, A. F. Park, M. J. Meyer, R. U. Lindquist, and R. T. Ethington. 2001. Evaluation of wet corn gluten feed in diets for lactating dairy cows. J. Dairy Sci. 84:2478-2485.

Van Soest, P. J., J. B. Robertson, and B. A. Lewis. 1991. Methods for dietary fiber, neutral detergent fiber, and nonstarch polysaccharides in relation to animal nutrition. J. Dairy Sci. 74:35833597.

Wildman, E. E., G. M. Jones, P. E. Wagner, R. L. Boman, H. F. Troutt, Jr., and T. N. Lesch. 1982. A dairy cow body condition scoring system and its relationship to selected production characteristics. J. Dairy Sci. 65:495-501. 